Dugald of the limits of thermal efficiency of gas and oil engines shows that 45 per cent. b.h.p. may be obtained in the near future. Sir Charles Parsons at the same time prepared an estimate of the limiting efficiency of the steam turbine as 28 per cent. Steam, internal-combusion, and gas engineers welcome the free competition with electricity supply, but consider that any attempt to crush out the smaller power units by a great Government scheme will act against the best interests of the country as to both coal conservam tion and economy in cost.

Sir Dugald also referred to the principle of heating towns by utilising the exhaust steam from steam turbines in central stations, and to Lord Kelvin's proposal to heat rooms by means of reversed Carnot cycle engines. By making full use of our water-power, three million horse-power could be added to the work of the country without consuming any additional coal

\section{Buddhism in the Pacific.}

$\mathrm{A}^{\mathrm{T}}$ a meeting of the Royal Anthropological Institute on Tuesday, May 18, Sir Everard im Thurn, president, in the chair, Sir Henry Howorth read a paper on "Buddhism in the Pacific." The paper discussed the disintegrated distribution of the Polynesian race, and the occurrence, especially in the Hawaian archipelago and that of New Zealand, of two of its factors which are separated by the whole length of the Pacific Ocean, one occurring in the extreme north and the other in the extreme south, and separated by an intervening area occupied largely by Melanesians. The two factors in question agree very closely in language, while they differ materially in the art and form of the objects which they use. Inasmuch as the Maoris almost certainly migrated to their present quarters at the beginning of the fifteenth century, this is the only way to account for the virtual identity of their speech with that of the Hawaians, and the general character of their ornamental work with that of the Melanesians. The Hawaians, on the other hand, present us with a series of objects, i.e. helmets and cloaks, made of feathers which, in their form and colour, differ entirely from those made by other members of the Polynesian race. They agree in an extraordinary way in colour and form with those of the Reformed Lamaists of Tibet, who, like other Buddhists, were great travellers and evangelists at a time when Chinese and Japanese vessels, as has been so completely proved in recent years, were traversing the Indian Ocean and visiting the whole of the eastern archipelago at least as far as New Guinea, and apparently even reaching New Zealand. where many years ago a very interesting bronze figure was found.

Sir Henry Howorth quoted instances of the drifting and wreckage of Chinese and Japanese vessels on the central and eastern Pacific during the time which has elapsed since Europeans first visited that ocean, and also the tradition of the Sandwich Islanders that several Japanese and Chinese ships had been wrecked among them in early times. It was not wonderful, therefore, that we should find their kings and gods adopting the stately dress used by the Lamas, the colours of which they imitated in feathers. All the details of the helmets exactly equate, while the cloaks are ornamented with patches of red on yellow or yellow on red, just as the Lamaist cloaks are, in the latter case in pursuance of the injunction of their founder that their cloaks must be ragged and patched.

In the interesting discussion which followed the reading of the paper, Dr. Glanvill Corney cited examples, some of which had come under his own NO. 2639 , VOL. IO5] observation, of the drifting of boats with native crews for long distances in the Pacific, and pointed out that the Polynesians were always ready to put out to sea. The Chinese had it on record that Buddhists visited Mexico at a very early date. The similarity shown by the helmets and cloaks of Hawaii and Tibet was very striking, and the explanation offered by Sir Henry Howorth was most probable.

Mr. Ray said that he himself for some years had been of the opinion that certain elements had been carried into Polynesia at least from Malaya, if not from farther-possibly Japan. The characteristic of the Polynesian was that he was very prone to imitate anything which took his fancy, as, for instance, European hats had been imitated. The Cambridge Expedition to the Torres Straits had found a club which was clearly an imitation of a Loyalty Islands club.

Mr. Hocart said that in dealing with the wanderings of the Polynesians too much stress had been laid on drifting, but deliberate purpose should be more emphasised. There was among the Polynesians a distinct passion for finding out new lands.

Dr. Forbes adduced as evidence of early movement Chinese objects which he had seen taken from Peruvian graves which were certainly pre-Inca in date.

Sir Everard im Thurn, in bringing the discussion to a close, said that Buddhist monks might well have accompanied the early voyagers in the Pacific. His attention had recently been directed to the question of the Hawaian helmets, and he wished to point out that the native peoples of the Pacific were verv fond of making head-coverings for use on ceremonial occasions. They paid great attention to the ornamental dressing of their hair, and if their hair were not suitable for this purpose they made artificial hair out of grass seed. He himself had brought back from Fiji an example of a native wig used in a ceremonial dance, which was now in the Pitt Rivers Museum at Oxford. It was probable, therefore. in view of this particular tendency, that the Hawaians would take readily to copying the head-dress of the Buddhists. This particular form of head-dress or helmet was not confined to Hawaii; objects ornamented with men's heads wearing head-dresses like those of Hawaii occurred in Hermit Island, near New Ireland.

\section{Astronomy at Oxford during the War.}

$W^{E}$ have recently received from Prof. $H . H$. Turner, of the Oxford University Observatory, a collection of papers published during the years 1914-19. These for the most part are reprints from the Monthly Notices of the Royal Astronomical Society, and represent researches carried out during this period by Prof. Turner and various members of his staff, including several volunteer workers who have rendered some valuable assistance. It is, of course, impossible adequately to discuss a miscellaneous collection of papers such as this in any detail, but there are several outstanding features of interest which call for special remark.

In the first place, a considerable number of the papers is devoted to an important research of Prof. Turner's on "A Proposal for the Comparison of the Stellar Magnitude Scales of the Different Observatories taking Part in the Astrographic Catalogue." This was first outlined at Paris in I909, the proposal being: "That the number of images recorded under each unit of the magnitude scale be counted and tabulated." The chief objects in view were to detect systematic errors of scale at the various collaborating observatories, and to test Prof. Kapteyn's conclusion that the Galaxy is relatively richer in faint 